\title{
Glacier and climate research on Hans Tausen Iskappe, North Greenland - 1995 glacier basin activities and preliminary results
}

\author{
Henrik Hфjmark Thomsen, Niels Reeh, Ole B. Olesen \\ and Peter Jonsson
}

A glaciological project was carried out between 1993 and 1995 on Hans Tausen Iskappe, a local ice cap in central North Greenland (Fig. 1). The project is funded by the Nordic Environmental Research Programme 1993-1997 launched by the Nordic Council of Ministers and by the European Union's third Framework Programme ENVIRONMENT, and is a collaboration between six institutions from Denmark, Iceland, Norway and Sweden.

The main goals of the project were to investigate the present and past climate and glacier dynamics of North Greenland by means of ice-core records, ice margin studies, mass balance and climate studies and glacial geological studies on and around Hans Tausen Iskappe. This ice cap was chosen for the following reasons: (1) Only very limited palaeoclimatic ice core data exist for North Greenland. (2) North Greenland is considered to be a region of high climatic variability and sensitivity, as indicated by Quaternary geological data and predicted by coupled atmosphere-ocean general circulation models (GCMs) (Funder et al., 1984; Bretherton et al., 1990).

The three years of work have mainly comprised field activities, with planning and reconnaissance in 1993 and an increasing level of field activities during the summers of 1994 and 1995. The activities can be divided into two main parts: ice core drilling and glacier basin investigations. Since most data and material were obtained during the 1995 field season, only preliminary analyses and data processing have so far been undertaken. This contribution deals mainly with the glacier basin activities during the summer of 1995; other activities are only briefly described.

\section{Hans Tausen Iskappe and locations of activities}

Hans, Tausen Iskappe is a local ice cap, about $75 \mathrm{~km}$ from north to south and $50 \mathrm{~km}$ from east to west, located in western Peary Land (Fig. 1). The ice cap has several domes (outflow centres) which reach elevations of 1200 to $1300 \mathrm{~m}$ a.s.l. Several outflow glaciers drain the ice cap to the west, north and east, often terminating at elevations of a few hundred metres; some reach sea level with a calving front. The southern margin of the ice cap can be characterised as a 'quiet' sector, often covered by snow drifts which survive the summer melt period.
Field work was mainly undertaken at two localities: (1) the southern dome; and (2) an outlet glacier basin including a dome in the north-east part of the ice cap (Fig. 1). The main activity in the southern dome region was ice core drilling to bedrock with associated measurements of ice thickness, strain-rate and velocity. The work in the outlet glacier basin constituted glacier-climate and mass balance studies, collection of ice and snow samples from the surface, and measurements of ice thickness, ice velocity and englacial temperatures. In addition glacial geological investigations were made in Nordpasset and at Adolf Jensen Fjord, north and west of the ice cap, respectively (Fig. 1).

\section{Field activities 1993}

A survey of surface and bedrock elevations was made in 1993 over the entire ice cap by radio-echo sounding from a Twin-Otter aircraft to identify a suitable general area for the deep drilling (Hammer, 1995). In addition, reconnaissance flights were made to locate suitable sites for the glacier basin investigations.

\section{Field activities 1994}

\section{Ice core drilling activities}

Detailed surface and bedrock elevations were measured from the ice surface within a $6 \times 6 \mathrm{~km}$ area centred on the intended drill site on the southern dome, using radio-echo soundings and kinematic GPS-positioning (Fig. 1). In addition, similar data were collected along two profiles, $16 \mathrm{~km}$ to the south-west and $6 \mathrm{~km}$ to the north of the drill site. A strain net was established and measured by GPS, and a $6 \mathrm{~m}$ ice core drilled for $\delta^{18} \mathrm{O}$ analysis (Hammer, 1995).

\section{Glacier basin activities}

A stake network for mass balance measurements and study of surface-ice velocity and deformation was established in the outlet glacier basin at the north-east part of the ice cap (Figs $1 \& 2$ ). The stakes were measured and positioned by GPS several times during the field season. Snow pit samples and firn cores were obtained from the 


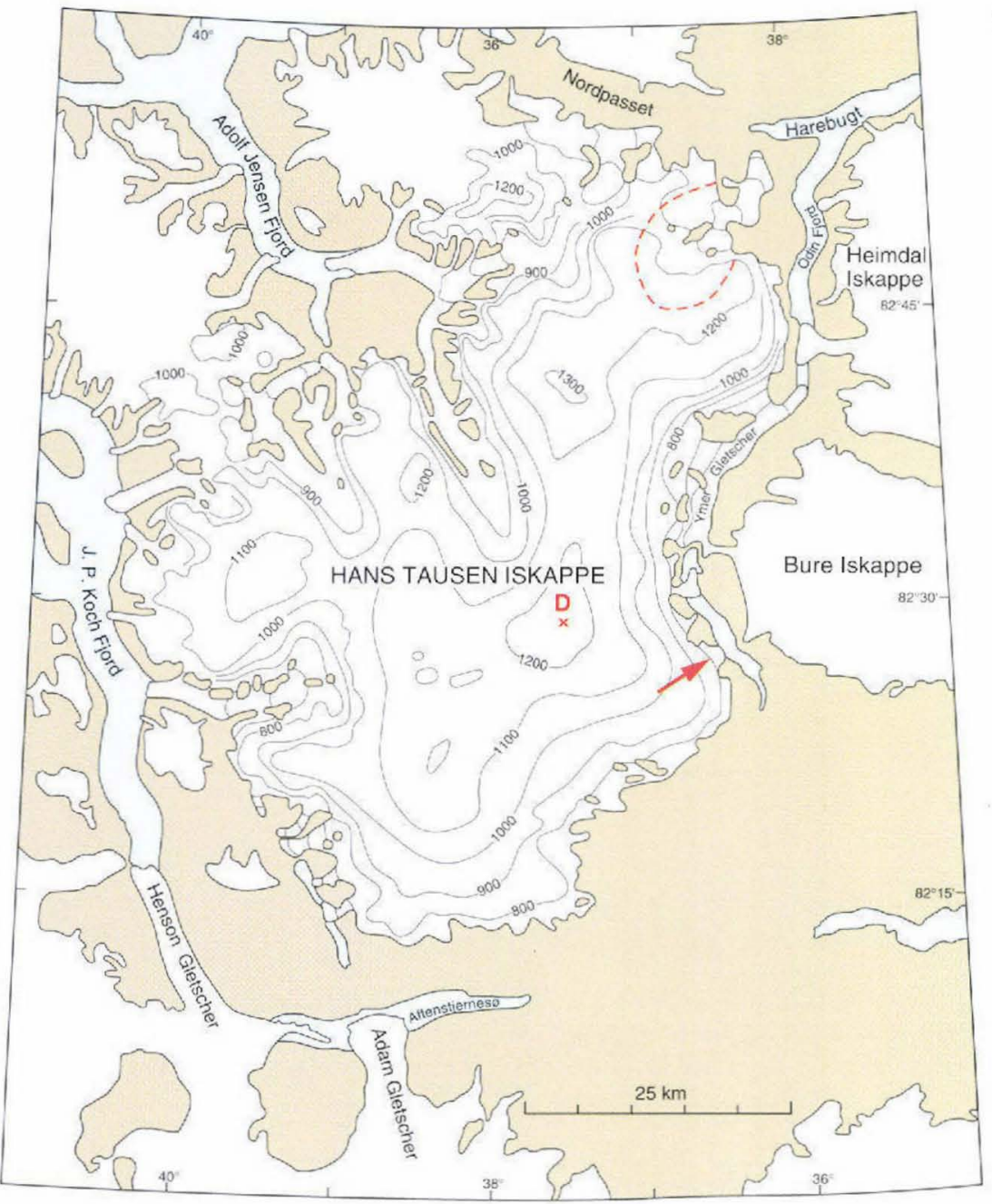

Hans Tausen Iskappe

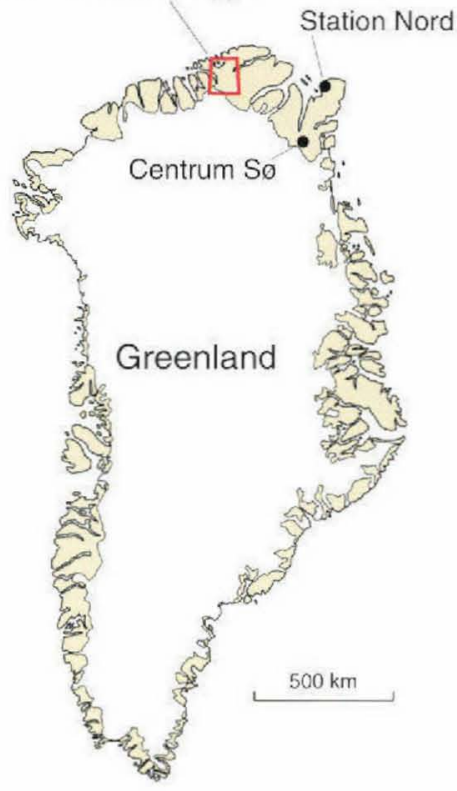

Fig. 1. Hans Tausen Iskappe. Map based on data from the National Survey and Cadastre, the Geological Survey of Denmark and Greenland and the Geophysical Department of the University of Copenhagen. D: Site of ice core drilling. Red dotted line: Limit of ice cap sector for glacier basin investigations. Enlarged map of this sector shown in Fig. 2. Red arrow: Location of surface ice sampling at an outlet glacier south-east of the southern dome. accumulation area of the basin, as well as measurements of englacial surface temperatures to a depth of $10 \mathrm{~m}$ at selected stakes.

Daily measurements of ablation in a 10-stake cluster were made together with logging of radiation components, ice albedo and simple climate data, including air temperature, humidity and wind speed (Braithwaite et al., 1995).

Surface-ice samples for $\delta^{18} \mathrm{O}$ analysis were collected in the ablation area, and samples of snow and firn from the accumulation area.

Lastly, glacial geological studies were carried out along the northern margin of Hans Tausen Iskappe with the aim of providing information about Holocene and earlier variations in ice cap extent (Landvik \& Hansen, 1994).

\section{Ice core drilling activities 1995}

In 1995 ice core drilling was made on the southern dome from the surface to bedrock and a $345 \mathrm{~m}$ long ice core of excellent quality was retrieved. In addition, an extra shallow core was drilled to a depth of $38 \mathrm{~m}$, and a pit was dug to obtain in situ samples for chemical studies in the porous upper metres of the ice cap (Hammer, 1995).

\section{Glacier basin activities 1995}

\section{Logistics}

Field work was carried out in two periods, in June and in August. In June equipment and personnel were transported to and from Hans Tausen Iskappe from Station Nord with a ski-equipped Twin-Otter aircraft. A base camp was established at the eastern margin of the outlet glacier (Fig. 1). Due to favourable snow conditions, except on the lowermost part of the glacier tongue where slush fields were developing, moving about in the area was generally easy using snow scooters. 


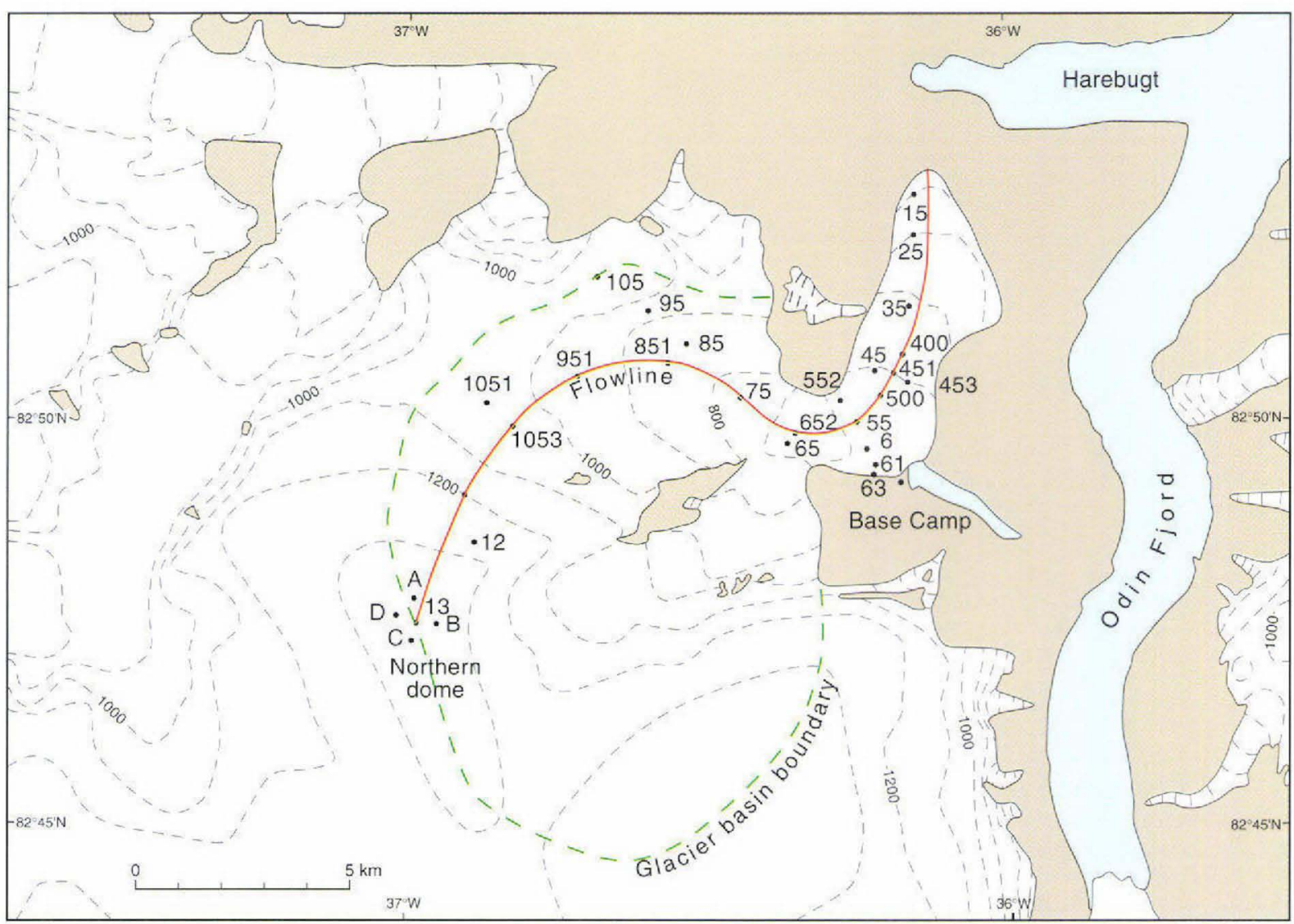

Fig. 2. North-eastem part of Hans Tausen Iskappe showing ice cap sector for glacier basin investigations (see also Fig. 1). Stakes for mass balance and ice velocity measurements are shown, as well as the central ice flow line from the northern dome to the glacier terminus.

In August equipment and personnel were transported to and from Hans Tausen Iskappe from a Survey base camp located at Centrum $\mathrm{S} \varnothing$ in Kronprins Christian Land, eastern North Greenland, with a combined helicopter and TwinOtter operation. Traffic on the ice cap in August was difficult due to the development of extensive deep slush fields, but helicopter support was only needed on one occasion.

\section{Ice-thickness measurements}

Ice-thickness measurements by radio-echo soundings were made in June, and covered the entire glacier basin (Fig. 2) using snow scooters to drag the radar system. The data will serve as input for ice flow modelling. The system used consists of a control and logging module, a generator, two antennae ( $80 \mathrm{MHz}$ high power transmitter and receiver) and connecting cables mounted on light-weight sledges (Jonsson, 1994).

A total of 70 line $\mathrm{km}$ of data were collected, including a $15 \mathrm{~km}$ long profile following the central flow line from the ice tongue to the northern dome (Fig. 2) and two profiles parallel to the central flow line but approximately $1 \mathrm{~km}$ to each side. In addition, several profiles perpendicular to the central flow line were made, together with a dense net of lines on the northern dome (Jonsson, 1995). Navigation was by low-resolution hand-held GPS receivers, with a more accurate tracking made by continuous kinematic GPS positioning. All data from the radio-echo survey were recorded in the field as graphic output on a line scan recorder and on cassette tapes. The data awaits further processing in combination with the GPS data. However, a comparison of ice-thickness data from the radio-echo sounding and hot water drilling around stake 451 (see below) shows that good quality data can be expected. Maximum ice-thicknesses of up to $350 \mathrm{~m}$ occur in the glacier basin, whereas the icethicknesses along the centre line of the glacier tongue range between $250 \mathrm{~m}$ and $300 \mathrm{~m}$; ice-thickness at the northern dome is about $250 \mathrm{~m}$.

\section{Hot water drilling for ice temperature measurements}

In order to measure englacial temperatures from the ice surface to the bottom of the ice it was planned to install 


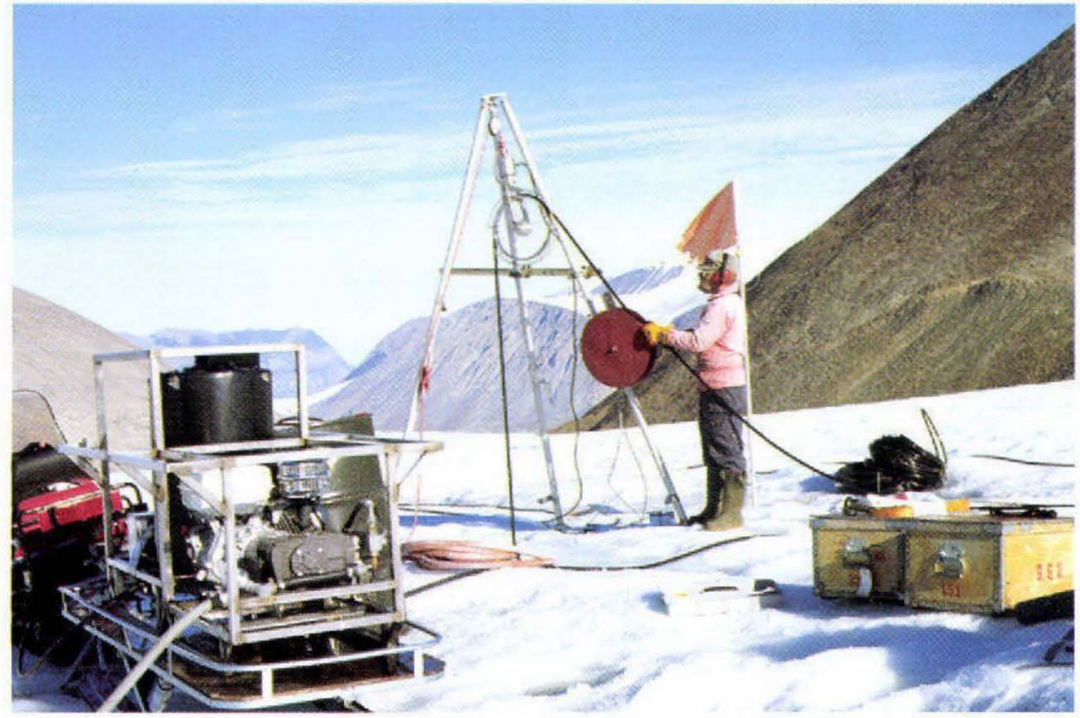

Fig. 3. Hot water drilling for installing thermistor string at stake $45 \mathrm{I}$ on Hans Tausen Iskappe.

thermistor strings at the two strain-net sites at stake 13 on the northern dome, at stake 451 on the glacier tongue and around the equilibrium line near stake 75 (Fig. 2). The englacial temperature data will serve as input for ice flow model studies. The holes were drilled with a hot water drill developed at the Survey (Olesen, 1989) and used in connection with glacier-hydrological studies on the Greenland ice sheet (Thomsen et al., 1989). However, due to very unfavourable drilling conditions only the thermistor string at stake 451 was successfully installed, reaching bedrock at a depth of $288 \mathrm{~m}$ below the ice surface (Fig. 3).

Temperature readings were made several times in the drill hole at stake 451 from 3 to 19 August. Similar temperature readings in hot water drill holes on White Glacier, Axel Heiberg Island, Canada (Blatter, 1985), showed that the temperatures are close to equilibrium state after 2 to 3 weeks, and the last readings at stake 451 on Hans Tausen Iskappe (on 19 August) are therefore assumed to be close to equilibrium (Fig. 4). The englacial temperature varies between $-18.5^{\circ} \mathrm{C}$ at $10 \mathrm{~m}$ depth to about $-1.5^{\circ} \mathrm{C}$ at the bottom. The relatively high temperature at the bottom was unexpected, but indicates that even a moderate climatic warming at the surface might bring the basal temperature in the marginal zone to the pressure melting point and result in increased ice flow velocities.

The planned drilling at stake 75 was abandoned due to the development of extensive deep slush fields at elevations higher than $700 \mathrm{~m}$ a.s.l. It was therefore decided to drill at stake 652 just below the stake 75 location where it was possible to move on the ice surface. The drilling went smoothly to a depth of about $120 \mathrm{~m}$, when the penetration of the drill slowed down, and at $220 \mathrm{~m}$ drilling was abandoned. These difficulties with the drilling are assumed to be due to the presence of rock debris layers in the ice, as stake 652 is located downflow of a large nunatak located in the central part of the ice cap sector (Fig. 2); a medial moraine can be followed on the ice surface down-glacier from the nunatak. Two further attempts to drill at a location between stake 652 and 75 and between stake 55 and stake 6 were abandoned for the same reason.

The drilling operation on the northern dome at stake 13 started on 14 August but had to be abandoned due to breakdown of equipment.

\section{Mass balance 1994/1995}

The stakes established in June 1994 between the northern dome at an elevation of about $1320 \mathrm{~m}$ and the terminus of the outlet glacier tongue at an elevation of about $220 \mathrm{~m}$ were visited on several occasions in June and August 1995, to measure the transit balance for the winter period 1994/95 and the summer period 1995, respectively. Ablation readings and snow soundings were made. In the accumulation area stake readings were made to record snow accumulation and melt. In addition, density profiles were made in the top few metres of the snow and firn in June and August to compare the profiles and detect the effects of summer melting and refreezing. Snow and firn samples for $\delta^{18} \mathrm{O}$ analysis were selected to investigate possible fractionation in the accumulation area in connection with refreezing and formation of superimposed ice. The snow and firn densities were measured in June and August to a reference level of $2 \mathrm{~m}$ depth, which was assumed to be below the depth of maximum percolation; experience from the Devon Island ice cap in Arctic Canada has shown that the depth of maximum percolation there is less than $2 \mathrm{~m}$ (Koerner, 1970). The density measurements were made in snow pits and samples were taken from the walls of the pit. Samples below 


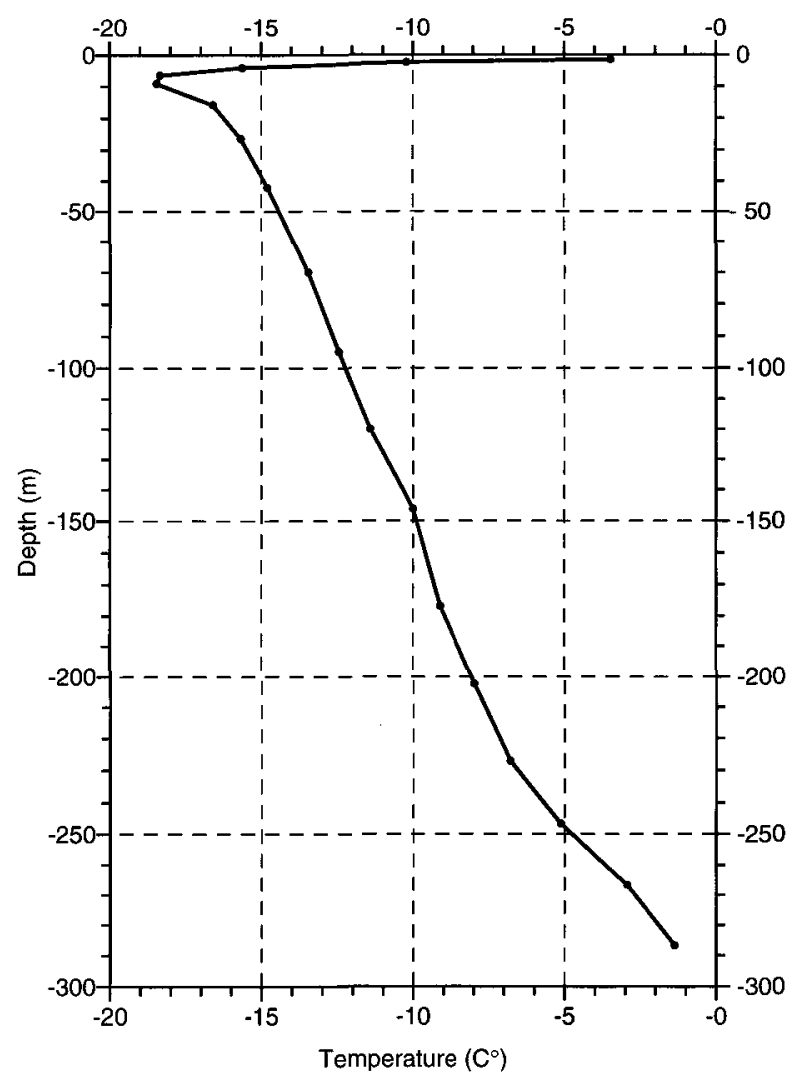

Fig. 4. Temperature-depth profile on the glacier tongue at stake 451 . The glacier bottom is at a depth of $288 \mathrm{~m}$.

the snow pit were taken using a SIPRE corer.

Mass change measurements in the accumulation area show that all melting refreezes in the snow and firn, together with any small amounts of summer precipitation. The exact values of the area mass change are uncertain, because the measurements only represent one point at each location. However, the general trend for all measured locations in the accumulation area shows that the transient balance for the summer period is close to zero. The mass balance study also showed that slush, several decimetres thick, develops late in the melt season over extensive areas of the glacier basin. Measurements indicate that most slush refreezes to form ice layers in the snow and firn or superimposed ice. This process releases energy (latent heat) causing local warming of the surface-near layers of the glacier, which is confirmed by measurements of ice temperatures in the top $10 \mathrm{~m}$ of the glacier at several locations.

To explain the melting and refreezing processes, further work is needed, including modelling of the temperature in the snow and firn based on the recorded near surface temperature data. This also includes the analysis of snow and firn $\delta^{18} \mathrm{O}$ values to study possible seep-away of summer snow with high $\delta^{18} \mathrm{O}$ values and fractionation in connec- tion with refreezing of melt water. The preliminary annual balance values vary from ablation of more than $1.5 \mathrm{~m}$ of ice per year at an elevation of $200 \mathrm{~m}$, to accumulation of about $0.3 \mathrm{~m}$ ice equivalent at an elevation of about $1300 \mathrm{~m}$; balance occurs at around $700 \mathrm{~m}$.

\section{Ice velocity and deformation measurements}

Ice flow velocities were measured by repeated relative GPS surveys at all stakes in the north-east glacier basin (Fig. 2). This data will serve as input for ice dynamic modelling. The stakes established and positioned in 1994 were re-positioned twice in 1995, in June and August. Strain rates were determined in three strain nets, one at the northern dome, one just below the equilibrium line at about $700 \mathrm{~m}$ a.s.l. and one at a location on the central part of the glacier tongue at an elevation of about $500 \mathrm{~m}$ a.s.l. All data have been processed to give preliminary summer, winter and annual values of vertical and horizontal velocities, as well as flow directions. The data show that horizontal surface ice velocities on the glacier tongue range from about $5 \mathrm{~m} / \mathrm{yr}$ near the terminus to about $50 \mathrm{~m} / \mathrm{yr}$ near the equilibrium line at about $750 \mathrm{~m}$ a.s.l. (Fig. 6) In the accumulation area, velocities are typically a few metres per year.

\section{Stable isotope studies}

In 1994 surface ice, snow and firn samples for $\delta^{18} \mathrm{O}$ analysis were collected along the stakes in the glacier basin for comparison with the $\delta^{18} \mathrm{O}$ record from the ice core at the southern dome. Preliminary analysis of the glacier basin samples showed unexpected large variations and trends (Fig. 6). In order to make a meaningful comparison of the $\delta^{18} \mathrm{O}$ record from the surface of the ablation area with the deep drilling record, the surface $\delta^{18} \mathrm{O}$ record needs to be corrected for variations in the $\delta^{18} \mathrm{O}$ content of the ice in the accumulation area of the glacier basin. Samples from snow pits and SIPRE corings in the accumulation area of the glacier basin reveal a pronounced 'reverse' relationship of $\delta^{18} \mathrm{O}$ with elevation; Fig. 6 illustrates a $4.5 \%$ increase of $\delta^{18} \mathrm{O}$ in the accumulation area for a $550 \mathrm{~m}$ increase of elevation.

In order to shed light on the cause of these variations in $\delta^{18} \mathrm{O}$ a more detailed sampling programme was carried out in August 1995; samples were taken at all stakes from stake 25 to 652 , as well as at locations between the stakes. A total of 290 ice samples were taken from the glacier tongue area with 10 samples collected at each location; a further 60 samples of snow and firn were taken from the accumulation area during pit work and SIPRE coring.

The new repeated sampling confirmed the results from the 1994 sampling programme.

A similar 'reverse' $\delta^{18} \mathrm{O}$ trend was found in the ice core 

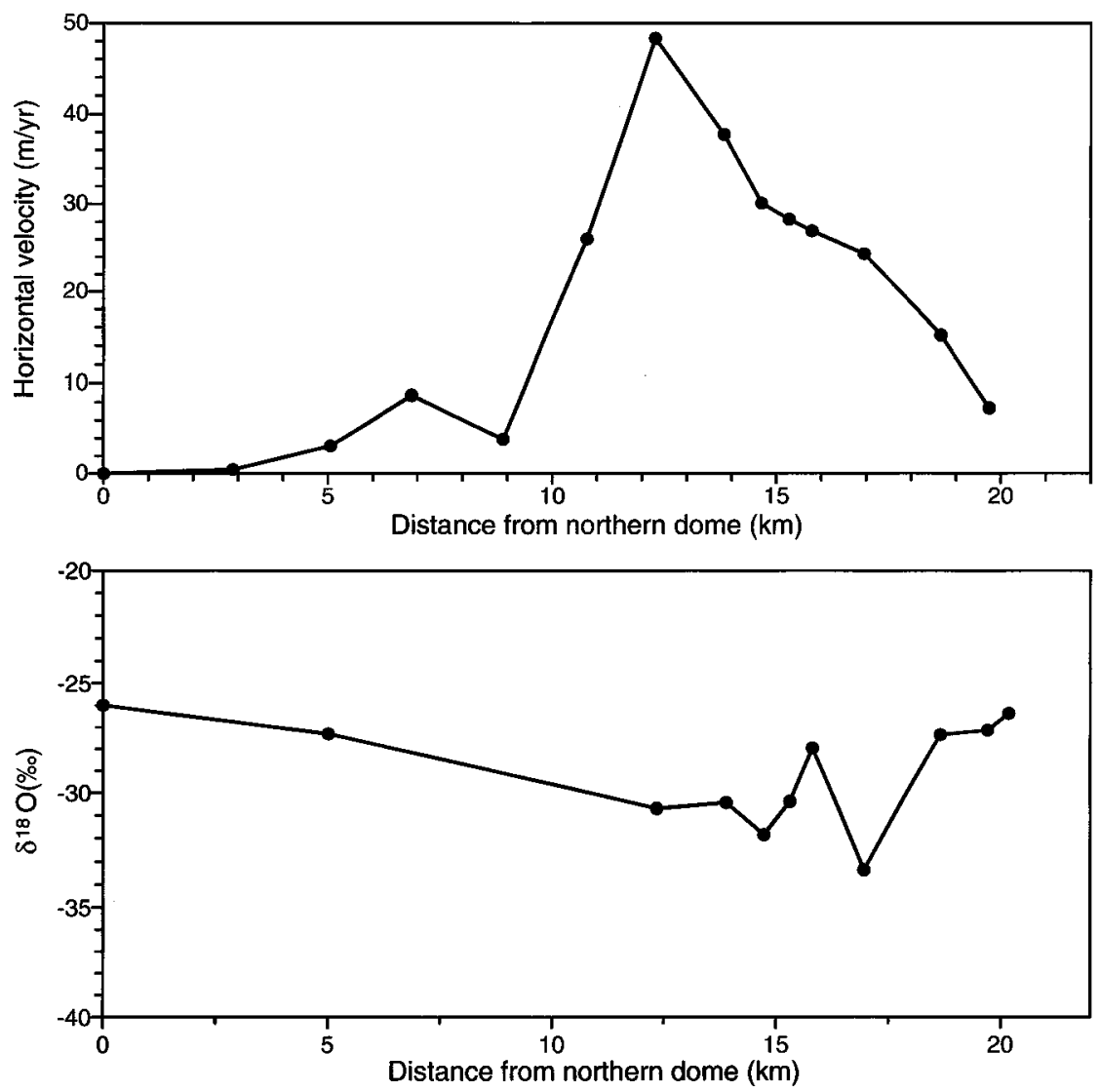

Fig. 5. Variation of horizontal ice surface velocity along the central ice flow line in the north-eastern glacier basin of Hans Tausen Iskappe. For location of central ice flow line see Fig. 2.
Fig. $6 . \delta^{18} \mathrm{O}$ variation along the central ice flow line in the north-eastern glacier basin of Hans Tausen Iskappe based on sampling in 1994. For location of central ice flow line see Fig. 2 . The equilibrium line is about $11 \mathrm{~km}$ from the northern dome. The 'reverse' $\delta^{18} \mathrm{O}$ trend in the accumulation basin $(0-11 \mathrm{~km})$ is confirmed by additional samples collected in June 1995. drilled at the southern dome (Hammer, 1995), which showed $\delta^{18} \mathrm{O}$ values $1.5 \%$ lower in the bottom $100 \mathrm{~m}$; such trends have no counterpart in other Arctic ice cap cores. Both reverse relationships might be due to heavy summer melting leading to the summer snow with high $\delta^{18} \mathrm{O}$-values seeping away through the snow pack. This explanation is supported by the observation of extensive slush fields developed at elevations up to $1000 \mathrm{~m}$ in the accumulation area of the ice cap during July-August 1995.

Surface ice samples collected in 1994 near the terminus of the glacier tongue and on a glacier tongue south-east of the ice core drilling location on the southern dome (Fig. 1) indicated that ice from the last ice age was not present at the margin of Hans Tausen Iskappe. To confirm this observation 300 additional ice samples were collected in 1995 near the ice core drilling location along a two kilometre profile covering the outermost part of the ice tongue; the sampling interval was $5 \mathrm{~m}$ for the outermost kilometre, and $10 \mathrm{~m}$ for the remainder of the profile. This additional sampling confirmed the observation that ice from the last ice age is not present, suggesting that the ice cap may have melted away completely during the Holocene climatic optimum. The $\delta^{18} \mathrm{O}$ record from the ice core drilled to bedrock at the southern dome of Hans Tausen Iskappe in spring 1995 supports this hypothesis; Holocene $\delta^{18} \mathrm{O}$ values are present throughout (Hammer, 1995).

\section{Discovery of biogenic material in the ice}

During a foot traverse on August 19 a musk-ox carcass was found on the ice surface $500 \mathrm{~m}$ east of stake 400 on the glacier tongue (Fig. 2). Individual body parts were more or less intact, but distributed over a $10 \mathrm{~m}$ long stretch parallel with the direction of ice movement. Excavations in the ice upstream of the carcass revealed musk-ox meat and fur continuing down into the ice, indicating that the musk-ox had been transported within and melted out of the ice. Selected body parts were brought home for biological investigations and ${ }^{14} \mathrm{C}$ dating.

The discovery of the musk-ox may serve as an interesting natural tracer for dating the ice. However, this will depend on how the musk-ox was originally incorporated into the ice. Preliminary calculations of the age of the ice at the location of the discovery indicate an age of 500-1000 years.

\section{Preliminary conclusions}

The $\delta^{18} \mathrm{O}$ surface ice sampling programme indicates that ice from the last ice age is not present at the margin of 
Hans Tausen Iskappe, a conclusion supported by the ice core drilled at the southern dome (Hammer, 1995). The ice cap must thus have melted away completely during the Holocene climatic optimum. Glacial geological studies to the north of the ice cap carried out in 1994 (Landvik \& Hansen, 1994), and earlier investigations south and west of the ice cap (A. Weidick, personal communication, 1995), show that areas adjacent to the present ice cap margin became ice-free after the last ice age about $6000-7000$ years ago. It is thus likely, that any earlier ice cap became extinct some time after $6000 \mathrm{BP}$, and that the present Hans Tausen Iskappe started to build up in the mid-Holocene. By contrast, the Canadian Arctic ice caps at similar high northern latitudes can be shown to have survived the Holocene climatic optimum, which might indicate that eastern North Greenland is highly sensitive to climate change.

Results of the mass balance and englacial temperature studies, and studies of $\delta^{18} \mathrm{O}$ variations, indicate the existence of an efficient warming mechanism probably due to development and refreezing of extensive slush fields. The heat produced may propagate to the bottom of the ice and raise the temperature of the basal layers with the effect of increasing ice flow velocities and enhancing the tendency for ice cap deterioration. Similar, but more pronounced, conditions are likely to have occurred during the Holocene climatic optimum leading to disintegration of the ice cap.

To quantify this conclusion in terms of modelling the varied processes involved, will require a major effort of data analysis, compilation and interpretation, as well as developing and running models for glacier mass balance and thermodynamics.

Acknowledgements. The GPS positioning was undertaken with Trimble receivers kindly loaned by the Department of Geophysics, Niels Bohr Institute, University of Copenhagen and the National Survey and Cadastre, Copenhagen.

\section{References}

Blatter, H. 1985: On the thermal regime of Arctic valley glaciers; a study of the White Glacier, Axel Heiberg Island, and the Laika Glacier, Coburg Island, N.W.T., Canada. Züricher Geographische Schriften 22, 107 pp.
Braithwaite, R. J., Marty, C. \& Olesen, O. B. 1995: Ablation and energy balance on Hans Tausen ice cap, Summer 1994. In Reeh, N. (ed.) Report on activities and results 1993-1995 for Hans Tavsen Ice Cap Project - Glacier and Climate Change Research, North Greenland. NMR (Nordisk Minister Råd) Miljøforskningsprogram - klimaforskning, 16-28.

Bretherton, F. P., Bryan, K. \& Woods, J. D. 1990: Time-dependent greenhouse-gas-induced climate change. In Houghton, G. J., Jenkins, G. J. \& Ephraums, J. J. (ed.) Climate change - the IPCC scientific assessment. Cambridge Univ. Press, 173-193.

Funder, S., Bennike, O., Mogensen, G. S., Noe-Nygaard, B., Pedersen, S. A. S. \& Petersen, K. S. 1984: The Kap København Formation, a late Cainozoic sedimentary sequence in North Greenland. Rapp. Gronlands geol. Unders. 120, 9-18.

Hammer, C. U. 1995: Ice core drilling. In Reeh, N. (ed.) Report on activities and results 1993-1995 for Hans Tavsen Ice Cap Project - Glacier and Climate Change Research, North Greenland. NMR (Nordisk Minister Råd) Miljøforskningsprogram klimaforskning, 16-28.

Jonsson, P. 1994: Mission report on an impulse radar experiment at NE Greenland. Lund University, Dept. Engin. Geol. Report ISRN: LUTVDG/TVTG-3046-SE, 7 pp.

Jonsson, P. 1995: Mission report on an impulse radar experiment at NE Greenland. Lund University, Dept. of Engin. Geol. Report ISRN: LUTVDG/TVTG-3047-SE, 8 pp.

Koerner, R. M. 1970: The mass balance of the Devon Island ice cap, Northwest Territories, Canada, 1961-66. J. Glaciol. 9(57), 325-336.

Landvik, J. Y. \& Hansen, A. 1994: The glacial history along the northern margin of the Hans Tavsen Ice Cap, North Greenland. In Henriksen, N. (ed.) Express Report Eastern North Greenland 1994. Unpubl. internal report, Gronlands geol. Unders., 115-119.

Olesen, O. B. 1989: A Danish contribution to the family of hotwater glacier drills. In Rado, C. \& Beaudoing, D. (ed.) Ice core drilling. Proc. Third Internat. Workshop on Ice Drilling Technology, Grenoble, France, 10-14 Oct. 1988, 140-148.

Thomsen, H. H., Thorning, L. \& Olesen, O. B. 1989: Applied glacier research for planning hydro-electric power, Ilulissat/ Jakobshavn, West Greenland. Ann. Glaciol. 13, 257-261.

H. H. T. \& O. B. O., Geological Survey of Denmark and Greenland

N. R., Danish Polar Center, Strandgade $100 \mathrm{H}, \mathrm{DK}-1401 \mathrm{Co}$ penhagen $K$

$P$. J., Department of Engineering Geology, Lund University of Technology, P. O. Box 118, S-221 00 Lund, Sweden 